Prácticas Mestizas. Metáfora para pensar el presente y el futuro

Paula Inés Porta, Mariana Ferrarelli

Question/Cuestión, Nro.70, Vol.3, diciembre 2021

ISSN: 1669-6581

URL de la Revista: https://perio.unlp.edu.ar/ojs/index.php/question/

IICom -FPyCS -UNLP

DOI: https//doi.org/10.24215/16696581e609

\title{
Prácticas Mestizas
}

Metáfora para pensar el presente y el futuro

\section{Mestizo Practices}

Metaphor to think about the present and the future

Paula Inés Porta

Facultad de Periodismo y Comunicación Social

Universidad Nacional de La Plata

paulainesporta@gmail.com

https://orcid.org/0000-0002-1399-1400

\section{Mariana Ferrarelli}

Magíster en Metodología de Investigación, UNLa.

Universidad de San Andrés 


\section{Resumen}

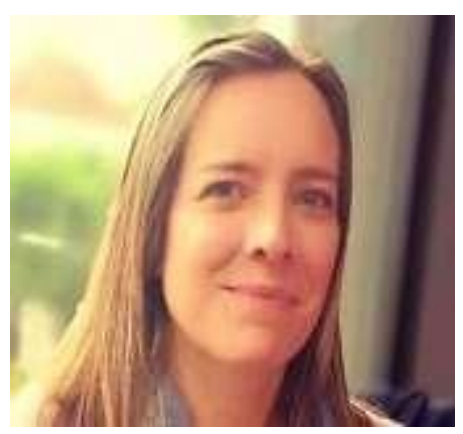

Las prácticas mestizas, se podrían pensar como un modo de hacer que se sostiene desde diversas miradas, voces o disciplinas que allí se mezclan. Pensar la propia práctica como una convergencia de diversidades. En lo aúlico uno puede mezclar disciplinas, maneras de hacer, formatos; incluye lo sincrónico y lo asincrónico, lo digital y lo analógico pero no exclusivamente. También apuesta por los diálogos, por la apertura hacia múltiples mediaciones: la tecnológica, culturales, económicas, ideológicas, políticas e incluso mediaciones éticas. Prácticas Mestizas: apertura hacia cruces varios, y esta idea de cruce nos permite pensar el aula como zona de frontera bilingüe.Es una idea de Baricco en "The Game" que se articula con Freire: el docente como cruzador de fronteras, Jesús Martín Barbero, la interacción de Bajtin, hay mucha cosa del sentido de lo poscolonial de los estudios culturales que nutren la comunicación que ahora se activaron. Pensar el aula como una zona de frontera donde estamos como en el medio en donde convergen diferentes tiempos/espacios sujetos, lenguas y formatos me parece la mejor definición para este momento.

Palabras Clave: Mediaciones, Prácticas, Aulas 


\begin{abstract}
Mestizo practices could be thought of as a way of doing that is sustained from different perspectives, voices or disciplines that are mixed there. Think of your own practice as a convergence of diversities. In the aúlico one can mix disciplines, ways of doing, formats; includes synchronous and asynchronous, digital and analog but not exclusively. It is also committed to dialogues, to openness towards multiple mediations: technological, cultural, economic, ideological, political and even ethical mediations. Mestizo practices: openness towards various crossings, and this idea of crossing allows us to think of the classroom as a bilingual border area. It is an idea of Baricco in "The Game" that is articulated with Freire: the teacher as border crosser, Jesús Martín Barbero, the interaction of Bakhtin, there is much of the sense of the postcolonial of the cultural studies that nurtures the communication that is now activated.Thinking the classroom as a border area where we are as in the middle where different times / spaces, subjects, languages and formats converge seems to me the best definition for this moment.
\end{abstract}

Key Words: Practical, Mediations, Classrooms

Link audio: https://go.ivoox.com/rf/79731707

\title{
Mariana Ferrarelli
}

Licenciada en Ciencias de la Comunicación (UBA), magíster en Metodología de Investigación (UNLa), y docente de grado y posgrado. Diseña y acompaña proyectos transmedia en distintas instituciones donde se desempeña como consultora tecnopedagógica. Dicta cursos de formación docente en la Universidad de San Andrés, la Universidad Isalud y en diversas universidades nacionales.. Escribe artículos académicos y desarrolla capacitaciones sobre los siguientes temas: narrativas transmedia en educación, trabajo con diversidad en el aula, tecnologías en la enseñanza, y el impacto de la cultura digital en las prácticas sociales. 


\section{Paula Inés Porta}

Doctora en Comunicación Social (FPCS-UNLP, 2015) Docente en grado y posgrado. Es miembro del Instituto de Investigación en Comunicación (IICom). Dirige tesistas de grado y posgrado, proyectos de investigación y becarios. Ha publicado libros, capítulos de libros y artículos en revistas nacionales e internacionales. Sus principales temas de trabajo son: comunicación, tecnologías y prácticas socioculturales. 